\title{
Deteksi Kandungan Babi pada Makanan Berbahan Dasar Daging di Kampus Universitas Al Azhar Indonesia
}

\author{
Riris Lindiawati Puspitasari $^{1 *}$, Dewi Elfidasari ${ }^{1}$, Analekta Tiara Perdana1 \\ ${ }^{1}$ Program Studi Biologi, Fakultas Sains dan Teknologi, Universitas Al Azhar Indonesia \\ Jl. Sisingamangaraja, Kompleks Masjid Agung Al Azhar, Kebayoran Baru Jakarta Selatan 12110 \\ Penulis untuk Korespondensi/E-mail: riris.lindiawati@uai.ac.id
}

\begin{abstract}
Abstrak - Makanan halal berarti makanan yang diijinkan dalam hukum Islam dan memenuhi syarat yaitu tidak mengandung material apapun yang tidak diperbolehkan dalam hukum Islam. Belum adanya informasi terkait kehalalan makanan yang terdapat pada makanan yang dijual di sekitar kampus UAI menyebabkan perlu dilakukan penelitian yang dapat memberikan informasi terkait kehalalan produk makanan yang dijual pedagang di sekitar kawasan tersebut terutama makanan berbahan daging. Penelitian ini bertujuan untuk mendeteksi cemaran daging babi pada makanan berbahan dasar daging yang dijual pedagang di kantin kampus UAI. Metode yang dilakukan yaitu melakukan pengujian menggunakan Porcine detection kit terhadap sampel makanan berbahan daging. Kontrol positif yang dipakai yaitu sampel daging segar babi. Hasil pengujian menunjukkan bahwa seluruh sampel makanan (25 macam) tidak mengandung protein babi (hasil negatif). Dengan demikian makanan yang ada aman untuk dikonsumsi.
\end{abstract}

Abstract - Halal food was known as food that permitted in Islam and met the requirements of good materials which was allowed in Islamic law. The lack of information related to the halal food especially found in UAI had been directed the research to be carried out. This research would provide information regarding the halal food products sold in the area, especially meat-based foods. This study aimed to detect the contamination of pork in meat-based foods. The research used total sampling method. The method used porcine detection kit against samples of meat-based foods. Positive control used a fresh pork meat. The result showed that all food samples ( 25 foods) did not contain pork protein (negative results). This data revealed the that all foods were safe for consumption.

Keywords - Halal food, Porcine detection, Meat based food

\section{PENDAHULUAN}

$\mathrm{S}$ alah satu konsep halal dalam Islam adalah makanan haruslah tidak mengandung sedikit pun 'lard' atau lemak pangan yang diturunkan dari binatang babi. Kehadiran komponen lemak babi ini, serendah apapun kandungannya dalam bahan pangan, akan membawa makanan tersebut menjadi haram untuk dikonsumsi. Kehalalan merupakan persyaratan mutlak bagi setiap muslim untuk mengkonsumsi makanan, begitu pula keharaman makanan juga merupakan persyaratan mutlak bagi setiap muslim untuk tidak mengkonsumsi makanan [1]. Sejumlah produk makanan berbahan dasar daging ditemukan tercampur dengan daging babi, terutama pada makanan olahan daging sapi. Pencampuran daging babi tersebut bertujuan untuk menurunkan harga produksi menjadi relatif murah dibandingkan jika menggunakan bahan daging sapi asli. Penggantian daging sapi dengan daging babi sebagai bahan dasar atau bahan tambahan tersebut sebagian besar tidak diinformasikan kepada konsumen, padahal produsen semestinya menyampaikan informasi tersebut kepada konsumennya [2]. Oleh karena itu, deteksi cemaran babi pada produk makanan perlu dilakukan untuk melindungi konsumen [3].

Suatu pangan harus 'aman' yang artinya diperlukan upaya untuk mencegah kemungkinan cemaran biologis, kimia dan lain sebagainya, sehingga dapat mengganggu, merugikan dan membahayakan kesehatan, serta tidak bertentangan dengan agama, keyakinan dan budaya masyarakat. Produk pangan yang dibuat dengan campuran daging sangat sulit dibedakan dengan mata telanjang, karena sering kali 
daging tersebut sudah dihancurkan dan dicampur dengan berbagai bahan lain [4]. Di era globalisasi seperti sekarang ini, produk olahan daging dari beberapa negara dengan asal usul yang diragukan juga banyak beredar dan terkadang mengabaikan aturan keamanan pangan tersebut, terutama dalam hal keyakinan agama atau budaya [5].

Beberapa penelitian melaporkan bahwa saat ini masih banyak kasus pencemaran pangan dengan bahan yang haram seperti babi. Produk penyedap masakan ditemukan adanya bastosoytone dari babi, daging dendeng yang tercemar daging babi, bakso curah yang mengandung DNA babi dan lain sebagainya [6].

Saat ini teknologi biologi molekuler terus mengalami perkembangan dan memungkinkan pengujian cemaran daging babi dengan mudah. Pengujian cemaran daging babi dapat dilakukan dengan Porcine Detection Kit dan metode amplifikasi DNA menggunakan Polymerase Chain Reaction (PCR). Metode tersebut dapat mengidentifikasi jenis daging dalam produk olahan. Metode analisis menggunakan DNA juga sangat menguntungkan, karena dapat ditemukan pada semua tipe sel pada suatu individu dengan informasi genetik yang identik, selain itu DNA juga bersifat stabil [7]. Identifikasi keberadaan daging babi pada produk makanan mentah dan olahan juga menggunakan amplifikasi PCR [8]. Ekstraksi dan PCR DNA babi pada sampel daging impor berupa beef steak dan beef sausage. Analisis cemaran daging babi pada produk bakso sapi menggunakan Real Time Polymerase Chain Reaction (qPCR) [9].

Pengujian dengan rapid test telah banyak dilakukan. Deteksi kandungan protein babi pada produk makanan yang dijual di masyarakat juga telah memberikan informasi mengenai keberadaan protein tersebut [10], [11]. Sampel yang digunakan adalah daging segar, daging matang, dan gelatin. Berdasarkan riset tersebut ditemukan bahwa sampel makanan mengandung protein babi. Hasil dengan rapid test kemudian dibandingkan dengan metode molekuler dan imunologi. Deteksi menggunakan amplifikasi DNA dan ELISA menginformasikan adanya kesamaan hasil dengan rapid test yaitu sampel makanan uji mengandung babi.

Salah satu institusi pendidikan di wilayah Jakarta yang dikelilingi oleh penjual makanan adalah kampus Universitas Al Azhar Indonesia (UAI). Belum adanya informasi terkait kehalalan makanan yang terdapat pada makanan yang dijual di kampus
UAI menyebabkan perlu dilakukan penelitian yang dapat memberikan informasi terkait kehalalan produk makanan yang dijual pedagang di sekitar kawasan tersebut. Penelitian ini bertujuan untuk mendeteksi cemaran daging babi pada makanan berbahan dasar daging yang dijual pedagang di kampus UAI. Diharapkan hasil penelitian ini dapat menjadi sumber informasi terkait kehalalan makanan yang dijual oleh pedagang di kawasan tersebut.

\section{METODE}

Kegiatan penelitian dilakukan pada bulan Januari hingga September 2018, bertempat di laboratorium Biologi, Universitas Al Azhar Indonesia. Penelitian bersifat pemetaan terhadap adanya kandungan babi dalam makanan yang dijual di kantin UAI. Sampel makanan berupa makanan berbahan dasar daging ataupun produk olahan daging. Setiap pengujian sampel disertai dengan kontrol positif (daging babi segar).

Tahapan penelitian adalah pengumpulan sampel makanan berbahan daging, pemotongan menjadi ukuran kecil, pengujian dengan kit, pengumpulan data hasil deteksi, analisis data, dan penarikan kesimpulan. Sampel yang dianalisis berasal dari makanan yang dijual oleh pedagang makanan di kantin UAI. Sampel makanan yang diambil adalah makanan yang berbahan dasar ataupun olahan daging. Sampel makanan dimasukkan ke dalam plastik steril lalu dibawa ke laboratorium. Sampel dipotong menjadi bagian kecil kemudian dihaluskan.

Metode pengujian menggunakan Pork Detection Test/Porcine Test merupakan uji cepat immunochromatograhic (lateral flow) yang digunakan untuk pengujian kualitatif atau semikuantitatif penentuan antigen daging babi. Antigen dari sampel terikat oleh antibodi yang sangat spesifik melekat pada warna partikel mikro yang kemudian mengalir ke garis tes dan bercampur dengan antibodi babi hingga membentuk garis berwarna yang menunjukkan hasil positif. Hasil pembacaan dengan kit tersebut bersifat kualitatif (+/-) dan tingkat akurasi 0,1\% (5-10 ppm). Hasil dapat muncul setelah 5-10 menit. Sensitivitas kit sekitar 1/1000 $(0,1 \%)$ bagian dari antigen daging babi, setara dengan 5-10 mg antigen babi per kilogram bahan padat (50-10 ppm). 


\section{HASIL DAN PEMBAHASAN}

Makanan yang digunakan dalam penelitian merupakan kelompok produk makanan berbahan daging yaitu sosis, bakso, olahan daging, olahan ayam, dan olahan ikan. Kelompok produk sosis terdiri atas 4 macam makanan, bakso terdiri atas 3 macam makanan, olahan daging sapi terdapat 7 macam makanan, olahan daging ayam terdiri atas 6 macam makanan, dan olahan ikan terdiri atas 2 macam makanan. Hasil deteksi adalah sebagai berikut.

Tabel 1. Hasil deteksi produk olahan berbahan dasar

\begin{tabular}{|c|c|c|c|}
\hline $\begin{array}{c}\begin{array}{c}\text { Kelompok } \\
\text { produk }\end{array} \\
\end{array}$ & $\begin{array}{c}\text { Nama } \\
\text { Makanan }\end{array}$ & Kode & Hasil \\
\hline \multirow[t]{3}{*}{ Sosis } & Crepes & Sos1W4 & Negatif \\
\hline & $\begin{array}{l}\text { Okonomiyaki } \\
\text { Nasi goreng } \\
\text { sosis }\end{array}$ & Sos2W4 & Negatif \\
\hline & Roti sosis & Sos4W7 & Negatif \\
\hline \multirow[t]{2}{*}{ Bakso } & Batagor kuah & Bks1W3 & Negatif \\
\hline & $\begin{array}{l}\text { Cilok bakso } \\
\text { Nasi goreng } \\
\text { bakso }\end{array}$ & Bks2W5 & Negatif \\
\hline \multirow[t]{4}{*}{ Olahan daging } & $\begin{array}{l}\text { Beef teriyaki } \\
\text { Crepes (beef } \\
\text { burger) }\end{array}$ & Dag1W2 & Negatif \\
\hline & $\begin{array}{l}\text { Smoke beef } \\
\text { Nasi goreng } \\
\text { kornet }\end{array}$ & Dag3W4 & Negatif \\
\hline & Roti abon sapi & Dag5W7 & Negatif \\
\hline & $\begin{array}{l}\text { Roti beef } \\
\text { Risol Smoke } \\
\text { beef }\end{array}$ & $\begin{array}{l}\text { Dag6W7 } \\
\text { Dag7W7 }\end{array}$ & Negatif \\
\hline \multirow[t]{5}{*}{ Olahan ayam } & Chicken karage & Aym1W2 & Negatif \\
\hline & Chicken teriyaki & Aym2W2 & Negatif \\
\hline & Spicy chicken & Aym3W2 & Negatif \\
\hline & $\begin{array}{l}\text { Chicken katsu } \\
\text { Risol chicken } \\
\text { teriyaki }\end{array}$ & Aym4W2 & Negatif \\
\hline & Egg roll & Aym6W2 & Negatif \\
\hline \multirow[t]{3}{*}{ Olahan ikan } & Siomay & Sio1W3 & Negatif \\
\hline & Otak-otak & Sio2W3 & Negatif \\
\hline & $\mathrm{N}=25$ sampel & & \\
\hline
\end{tabular}

Berdasarkan Tabel 1 terlihat bahwa dari 25 sampel makanan yang dideteksi seluruhnya negatif yaitu tidak mengandung cemaran babi. Tidak terkandungnya material babi dalam sampel makanan mengindikasikan bahwa makanan yang dijual telah bebas dari kontaminan tersebut. Masuknya kontaminan material babi dapat terjadi selama proses persiapan, pembuatan, maupun penyajian. Sosis dan bakso merupakan produk olahan daging yang umum digunakan sebagai bahan tambahan dalam makanan. Masyarakat menyukainya karena mudah didapat, disimpan, dan diolah. Pada penelitian, sosis dan bakso yang digunakan sudah dalam bentuk variasi makanan sehingga membutuhkan proses awal sebelum dilakukan pendeteksian seperti pencucian. Deteksi kandungan babi secara kualitatif menggunakan kit merupakan prosedur yang sederhana, cepat, dan mudah aplikasinya [11].

Perbedaan daging babi dengan daging sapi secara kasat mata dapat dilihat berdasarkan warna, serat daging, tipe lemak, aroma dan tekstur. Warna daging babi lebih pucat dari daging sapi dan mendekati warna daging ayam. Namun demikian pada daging babi oplosan umumnya dilakukan pelumuran dengan darah sapi untuk kamuflase. Serat daging babi terlihat samar dan renggang. Kegiatan pencampuran daging babi dan sapi dapat menyebabkan kesalahan penentuannya terutama apabila sudah menjadi suatu produk olahan daging. Konsumen menjadi sangat kesulitan untuk mendeterminasinya. Untuk itu maka kejelian dalam memilih daging dengan memperhatikan karakteristik yang ada penting dipelajari. Pemetaan adanya cemaran daging babi menjadi salah satu sumber informasi agar konsumen terhindar dari kesalahan dan tetap terjamin kehalalan produk makanan.

Berdasarkan hasil terlihat tidak ditemukannya kandungan babi menunjukkan bahwa metode yang digunakan telah mampu mendeteksi protein babi. Metode tersebut sesuai bila digunakan untuk tes cepat dan diaplikasikan di lapangan karena tidak membutuhkan peralatan laboratorium yang lengkap. Namun demikian, pemeriksaan kandungan babi perlu juga dilakukan dengan berbasis protein dan DNA agar didapat hasil yang komprehensif terutama ketika ditujukan untuk perumusan suatu kebijakan. Hal tersebut telah dilakukan oleh penelitian lain yang menggunakan sosis sapi dari pasar tradisional dan modern di Yogyakarta. Hasil amplifikasi DNA babi pada 9 sampel sosis menunjukkan bahwa 8 sampel di antaranya mengandung DNA babi dan memiliki homologi sebesar $95 \%$ dengan spesies Sus scrofa (babi celeng) [4].

Berdasarkan informasi tersebut di atas maka diperlukan penelitian lanjutan yang mengkaji kandungan babi pada sampel sosis, bakso atau 
makanan jadi lainnya dengan menggunakan lebih banyak sampel dan metode terpilih berbasis DNA. Hal tersebut ditujukan agar didapat hasil penelitian yang spesifik, sensitif, dan komprehensif.

\section{KESIMPULAN}

Makanan berbahan dasar daging yang dijual di kantin UAI antara lain berupa sosis, bakso, olahan daging, olahan ayam, dan olahan ikan. Seluruh sampel makanan terdeteksi negatif atau bebas dari cemaran daging babi.

\section{UCAPAN TERIMA KASIH}

Penulis mengucapkan terima kasih kepada Lembaga Penelitian dan Pengabdian kepada Masyarakat atas bantuan Research Grant UAI tahun 2017/2018. Juga kepada Prodi Biologi atas dukungan laboratorium dan peralatan penunjang riset.

\section{REFERENSI}

[1] H. Asy'ari, "Kriteria makanan halal dalam perspektif Ibnu Hazm dan MUI," UIN Syarif Hidayatullah, Jakarta, 2011.

[2] E. T. Margawati and M. Ridwan, "Pengujian pencemaran daging babi pada beberapa produk bakso dengan teknologi PCR: Pencarian sistem pengujian efektif," Berita Biologi, vol. 10, no. 1, pp. 93-98, 2010.

[3] Zulfahmi, "Deteksi kontaminan babi pada produk makanan menggunakan teknologi melokuler DNA," Kutubkhannah, vol. 18, no. 1, pp. 1-6, 2015.

[4] V. A. Priyanka, "Deteksi cemaran daging babi pada produk sosis sapi di kota Yogyakarta dengan metode PCR," Universitas Atmajaya, Yogyakarta, 2017.

[5] I. A. Alaraidh, "Improved DNA extraction method for porcine contaminants, detection in imported meat to Saudi markets," Saudi Journal of Biological Science, vol. 15, no. 2, pp. 225-229, 2008.
[6] W. Sari, A. Krisna and E. P. Kurnia, "Deteksi molekuler cemaran daging babi pada bakso sapi di pasar tradisional kota malang menggunakan PCR," Pangan dan Agroindustri, vol. 3, no. 4, 2015.

[7] S. Jain, M. N. Brahmbhait, D. N. Rank, C. G. Joshi and J. V. Solank, "Use of cytochrome b gene variability in detecting meat species by multiplex PCR assay," Indian Journal of Animal Science, vol. 77, no. 9, pp. 880-881, 2007.

[8] J. H. Calvo, Z. P and O. R, "Technical note: A quick and more sensitive method to identify pork in processed and unprocessed food by PCR amplification of a new specific DNA fragment," Animal Science, vol. 79, no. 8, pp. 2108-2112, 2001.

[9] S. Rasyid, "Analisis cemaran daging babi pada produk daging bakso sapi yang beredar di wilayah Ciputat menggunakan Real Time PCR dengan metode hydrolisis probe," UIN Syarif Hidayatullah, Jakarta, 2014.

[10] J. Masiri, L. Benoit, C. Thienes, B. B. Lopez, M. Meshgi, A. Agapov, A. Dobritsa, C. Nadala and M. Samadpour, "Development and validation of a rapid test system for detection of pork meat and collagen residues," Meat Science, vol. 121, pp. 397-402, 2016.

[11] T. W. Murti, C. Y. Admantin, U. Santoso, D. A. Widiasih and A. Haryanto, "Fraud identification in meatballs products using porcine detection kit and multiplex PCR methods," in The 6th International Seminar on Tropical Animal Production, Yogyakarta, 2015.

[12] M. L. Puspita, "Makanan halalan thayyiban dalam Al Quran perspektif Al Qurtubi dan Ali Al Sabuni," UIN Sunan Ampel, Surabaya, 2019. 